\title{
Layout and shape of Dürer's Geschützrondellen in the Spanish defensive architecture: the horseshoe pattern in the Enlightenment
}

\author{
J. Lluis i Ginovart, J. M. Toldrà Domingo, A. Costa Jover, \\ S. Coll Pla \& P. de Sola Morales i Serra \\ Universitat Rovira i Virgili, Spain
}

\begin{abstract}
Most of the defensive structures of military architecture are based on polygonal shapes staked out by triangulation. There are few buildings designed with curved structures, as the pirobalistic platforms, Geschützrondellenas mentioned by Albert Dürer (1471-1528) in his Etliche underricht zu befestigung der Stett, Schlosz, und flecken (1527). The Spanish military engineer Pedro de Lucuze (1692-1779) defined a similar kind of fortifications, called horseshoe pattern in his Principios de Fortificación (1772). Before the publication of this treatise, several bulwarks were built in the Spanish coast, where we can find the geometrical forms of the oval and the ellipse.

The staking out of the ellipse appears in the treatises L'architettura (1567) by Pietro Cataneo, and Le Timon du Capitaine (1587) by Ambroise Bachot. There, the layout of the oval was made starting from one of its axis. Vicente Tosca (16511723) establishes for the first time in Volume I of his Compendio mathematic (1707) infinite solutions of ovals from the main axis. Through this knowledge, Spanish military engineers can approach similar layouts for ellipses and ovals. The geometrical assessment of the Fuerte de San Jorge de Alfama (c.1744) enables the analysis of the layout of the project as well as its staking out, recovering the old discussion of the ellipsis et ovum.
\end{abstract}

Keywords: military architecture, XVIIIth century, ellipse, geometry, oval.

\section{Introduction}

The appearance of the Artillery caused a strategic change in the conception of military defense. The Castle of Salses (1497-1503) built by Fernando I of Spain 
(1452-1516), is one of the first bastions adapted to cannons. The fortification was built adapting the Castilla tradition of fortification by Francisco Ramiro Lopez (Gonzalez [1]).

Albert Dürer (1471-1528) introduces the rotundas with artillery and the Pastey (bastion) into design treatises and the construction of Geschutzrondellen. He introduces it through his work Etiche underricht zu befestigung der Stett, Schlosz, und flecken (1527). The chapter 5 "Creating the platform of pirobalistic defense" (Dürer [2]), is compulsory reference to understand the defensive tipology of horseshoe pattern (fig. 1). Dürer draw bastions in function of flanks direction. Curved stretches were drawn through arches of circumference. The geometric problem of the intersection between straight stretches and arched stretches caused the introduction of ovals during Renaissance.
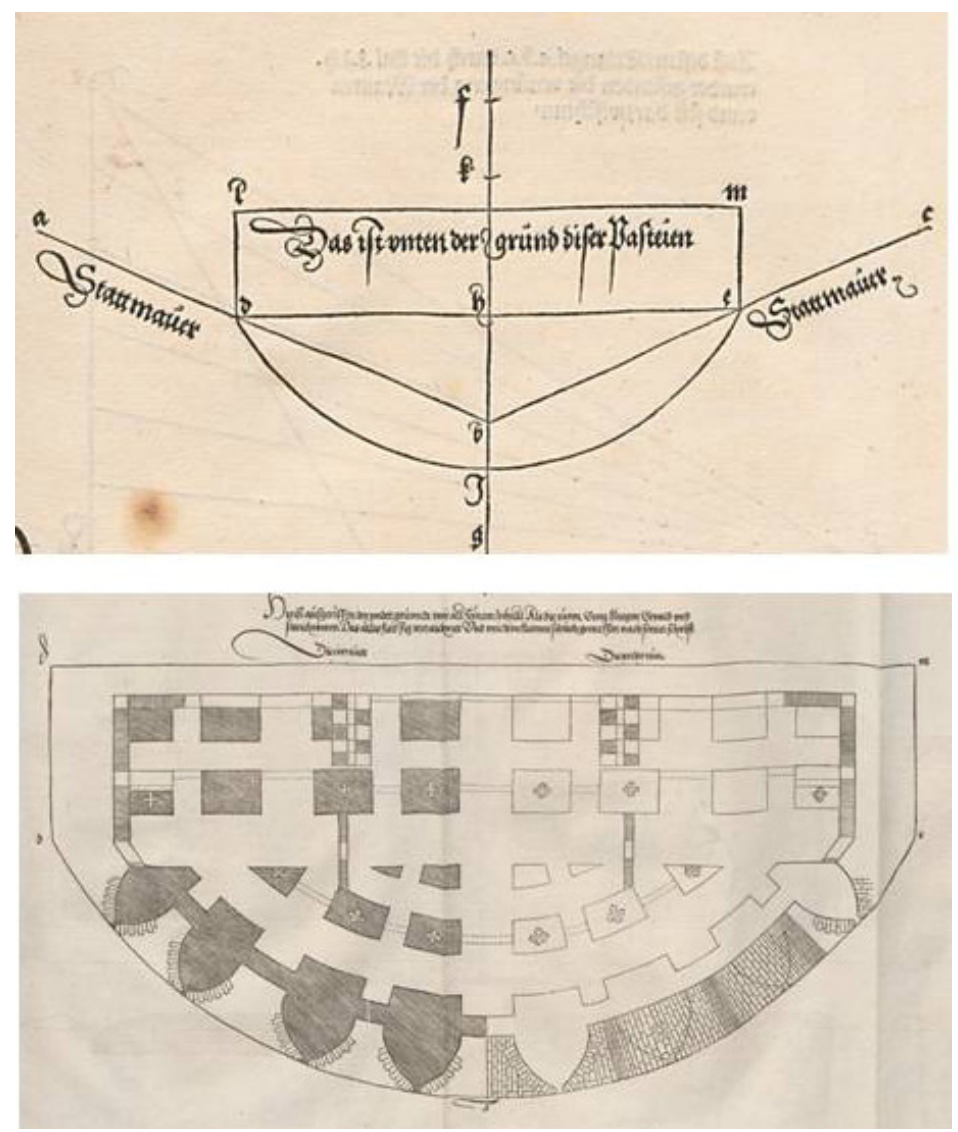

Figure 1: Composition of various plates by Albert Dürer (1527).

During the War of the Spanish Succession (1701-1713), Philip V (1683-1746) created the Royal Corps of Military Engineers (1711), and the Academy of Mathematics of Barcelona (1720), introducing the Enlightenment thought in 
Spain. Previously, the Habsburg dynasty had established the Academy of Mathematics regulating the powers of the King's Engineers in Madrid (1582) (1612) Brussels (1675) and Barcelona (1692).

The Spanish military treatises of the seventeenth and eighteenth century assume the universality conferred on mathematics by Cartesianism as a method for the investigation of reality, dealing with the causes and effects that perfect the world (Tello [3]). The engineer Diego Enrique Villegas (d. 1651) defined military architecture as a science that teaches its students about all the possible types of siege, based on their strength or weakness. Its foundations lie in mathematics and it is one of the parts into which it is divided (De Villegas [4]).

The engineer Andrés Davila y Heredia (d. 1672) explained the hierarchy which some parts of Mathematics retain within the arts, and states that Arithmetic and Geometry are the foundations for the others. Geometry is sovereign to such an extent that all its operations are considered for the use and success of the arts, because the architect is unable to work in any area without it (Davila [5]). According to the engineer José Chafrión (1653-1698), speculative Arithmetic considers the hidden properties of numbers and their practice and use (Chafrión [6]).

Based on these assumptions, the Spanish military engineers of the eighteenth century built a series of U-shaped batteries acting as artillery platforms. The classic discussion, ellipsis et ovum (Migliari [7]), is a direct reference to conic sections of mathematics, and their application in military architecture. The increased use of the string method for tracing the ellipse, as well as the dissemination of the ovals method in the Military Architecture treatises of the late sixteenth century, led to the discussion concerning the scale of the layout of one of these artillery platforms. The ellipsis et ovum discussion had a linguistic aspect from the perspective of applied mathematics. The geometric approaches to defensive constructions - both the ellipse and the oval - a negligible difference on the scale of construction.

The U-shaped layout appeared in the Principios de Fortificación (1772) written by Pedro de Lucuze (1692-1779) He described it as the most common type occurring in the batteries in a Fortress on the seashore, or the banks of a navigable river. The curvature of the bastion facilitates direct cannon shots in any direction. The entrance to the enclosure is located in the gullet or mouth of the "U", forming a small fortified front to defend the door from the flanks. The door is located in the middle of the retaining wall, and protected by a small pit (Lucuze [8]). The curved shape of the U-shaped fortification platform is not formally defined in the text by Lucuze. In some of the engineers' plans, the graphic representation of the curved shape simply consists of a circumference arc which is not even on a tangent to the flank.

\section{The Fort of San Jorge}

Shortly after the surrender of the city of Tortosa to the Duke of Orleans, on 15 July 1708, during the War of Spanish Succession (1701-1713), Philip V (1683-1746) appointed Jorge Prosper Verboom (1667-1744) as General Engineer on January 13, 1710. During the siege of the city of Barcelona (1712-1714), Alejandro de 
Retz, holder of the high rank in Flanders, was sent to Tortosa in 1712 and appointed Director of the Catalan Fortresses based in the city. One of the engineers' tasks was to construct batteries on the coast. The first stages saw the construction of the fort of Coll de Balaguer in around 1721, by the engineer Luis de Langot, Vauban's assistant, followed by the fort of San Jorge de Alfama (c. 1744) (fig. 2), and the defenses of San Carlos de la Rapita by Miguel Marin (1733), the defences of Puerto de los Alfaques, with the Tower of Sant Joan (1739) by Enrique Legallois de Grimarest, and Marcos de Serstevens (1748), in Alcanar.

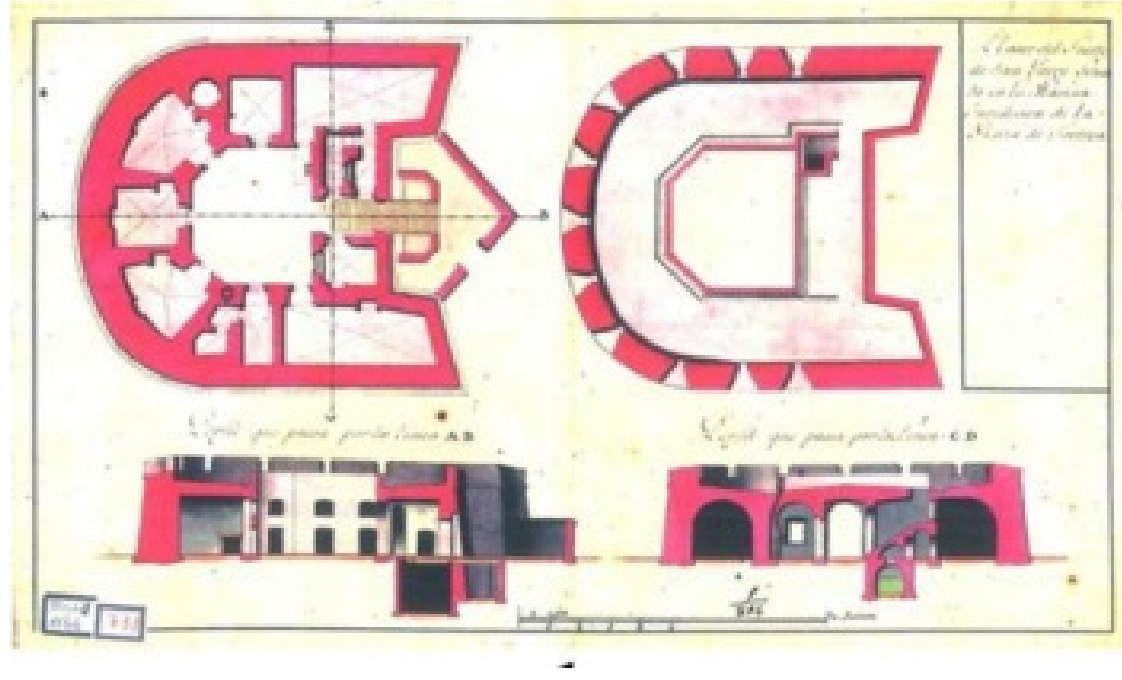

Figure 2: Battery of San Jorge de Alfama.

Various documents are available from the design and construction of the fort of San Jorge (c. 1744): Plan of the port of San Jorge, located in the harbour. Jurisdiction of the fortresss of Tortosa"; Plan of the fortress of San Jorge by López Sopeña (1740); Plan and outline of the gunpowder store in the Fort of San Jorge in the fortress of Tortosa."; Plan of the Fortress of San Jorge detached in Tarragona by Marcos Serstevens (1750); Plan of the Fort of San Jorge on the coast of the governorship of Tortosa and the last one going towards Barcelona by López Sopeña (1772).

The assessment of the original planimetry enables the deduction of the layout of the project (SHM, 9250). It was expressed in toesas $(1$ toesa $=6 \mathrm{feet}=1.946 \mathrm{~m})$ and should be performed using an oval, with the axis set at 12 toesas. The minor radius is 22 feet from the edge of the axis, and the center of the major radius is 18 feet from the center of the axis. Thus, the oval is inscribed in a rectangle of $72 \mathrm{x}$ 26.8 feet $(12 \times 4,46$ Toesas $)$ (Fig. 3a)). It is also possible to perform the layout of the project with an ellipse. The metrological design of the ellipse would allow a rectangle of $72 \times 27$ feet, with a focus located 9 feet from the axis of the fortification. 
A manual planimetric survey of the Fort of San Jorge was conducted in 1984, with a maximum deviation of $1 \%$ (Generalitat Catalunya

[9]). The metrology of the fortification's main walls and its measurements of width and height were seen to follow the metric of toesas. The measure of the front axis was $23.49 \mathrm{~m}(12,046$ toesas $)$ by $8.69 \mathrm{~m}(4,456$ toesas $)$. There was a tendency to assume that the battery was laid out by an ellipse with major axes of 12 and 4.5 Toesas. The commensurability of the measure led to a manual delineation of the

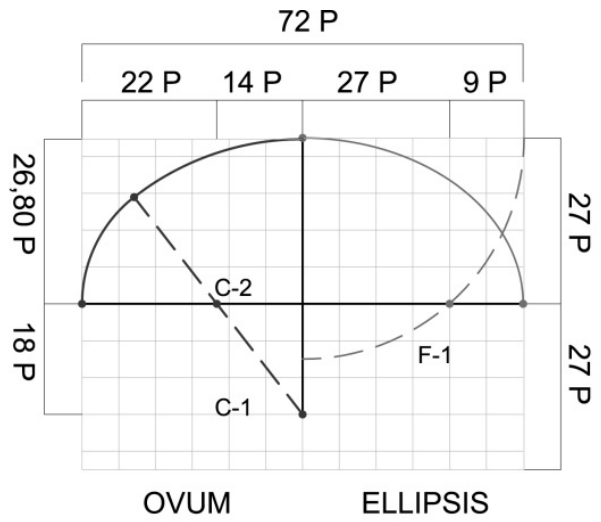

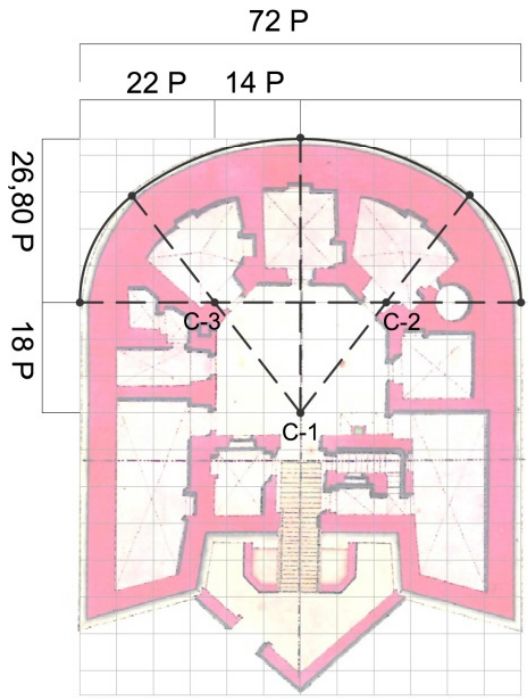

a)

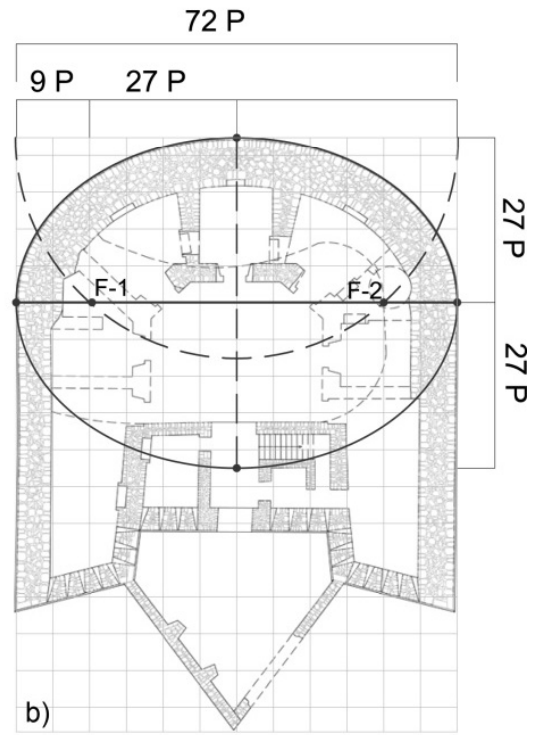

ELLIPSIS

OVUM

MENSURA PES TOESA

Figure 3: Geometrical survey of the Fort of San Jorge de Alfama (c. 1744). 
battery layout using the so-called gardener's or string method, for which it was necessary to construct an ellipsograph. Thus, the new survey was laid out with an elliptical construction (Fig 3b)).

\section{The ellipse and the oval in military defense constructions}

There is a fundamental difference between the two figures, derived from the Optics of the Enlightenment. The two figures are very different in terms of receiving impact and disrupting the thrust of the projectile. If the impact is perpendicular during the descent of the parabola, the disruption of the oval figure tends to be univectorial, passing through any of the three centers of the oval. In the ellipse, the impact tends to decompose into two vectors passing through the foci located on the major axis.

The discrimination between laying out the oval and the ellipse in the construction of U-shaped bastions is due to the need for the geometric layout of the plan and its subsequent transfer to the work. Semicircles were used for the delineation of these bastions as at Las Aguilas (1752) (AGS: MPD, 20, 056), as well as circumference arcs, in Marbella (1737) (AGS: MPD, 39, 066), but mostly ovals. The ovals' major axis was divided into three equal parts, in others it was metrological, and in others it was similar to the basket arch in the plans by Salobreña (1722) (AGS: MPD, 59, 032), Marbella (1732) (AGS: MPD, 39, 065), Campo de Gibraltar (1750) (AGS: MPD, 56, 038) and Los Alfaques (1779) (AGS: MPD, 08, 130). The main drawback of this type of oval is that it is difficult to transpose in the work, as it is necessary to perform several operations in order to lay out the centers.

The translation of the U-shaped work depended on two basic questions - the ease of its layout and the level of commensurability of the gauge of the "U". If the measures of the axes are commensurable it can be resolved, either by construction of the ellipse or of the oval. The construction of the ellipse, using a string, was described by Cataneo (1567), and Bachot (1587). The design of the ellipse in the work is immediate. With the two axes, the foci are determined and the ellipse is laid out continuously, unlike the oval, in which the center has to be changed. The foci require a compass operation at the end of the minor axis on the major axis of the battery. The difficulty with the figure lies in the construction of concentric ellipses, equidistant from main edges, as the focus changes position on the major axis.

Unlike the laying out of the work, the delineation of a plan with concentric ellipses is complex, as although various instruments were known; Jacques Besson (1540-1573) Circinus novus et universalis (P1.-5) (Besson [10]), Francesco Barozzi (1537-1604) Admirandum illud geometricum (1586), the perfect compass, (Barrozzi [11]) and the Bachot (1587), the engineers used the twopointed compass for its layout. The military engineers thus tended to use the oval using methods derived from Serlio (1545). With this method, the military engineer uses the width of the bastion, the major axis, and determines the minor axis using the layout method. The arrow of the " $U$ " has a measure which is derived and is therefore not measurable, as we have determined in most of the projects analyzed. 
Sebastiano Serlio (1475-1554) attempted to lay out the oval in Il Primo libro d'architettura, Le premier libre d'Architecture (1545). He identified four ways to trace the oval; the first one, based on the triangle, a second one from three circles, and another from two perfect squares and finally another with the use of two circles with touching centers (Serlio $[12,13])$. The constructions parameterized the major axis, and the minor axis was deduced from this. (Rosin [14]). This could only initially define the major axis of the oval. In Spain, Cristóbal Rojas (15551614) did not mention the layout of the oval, but used it in the stereotomy of sarpeinel arch, Par III. Chap. VIII, (Rojas [15]).

Serlio was widely read among the engineers of the Cinquecento. Niccoló Trataglia (1499-1577), in the Fifth part of the Trattato di numeri e misure (1560), considered the oval in Il modo geométrico et naturale da risolure com il compasso et rega varrii problema non posti da Euclide Chap. VII, (Tartaglia [16]), although he did not use Book VI of the Quesiti, et inventioni diverse de Nicolo Tartalea for these geometries, and decided on the triangle (Tartaglia [17]). In Spain, Cristóbal Rojas (1555-1614) did not mention the layout of the oval, but used it in the stereotomy of sarpeinel arch, Par III. Chap. VIII, (Rojas [18]).

Pietro Cataneo (d.1569) in L'architettura (1567), considered the oval (Book VII., Props. XII. XIII, XIIII and XIV). In Come si causi la figura ovale, con il filo (Prop. XIV) (Cataneo [19]) he mentions tracing an oval using the string method, but he is in fact tracing an ellipse, and is able to determine the measurements of the two main axes. In Le Timon du Capitaine (1587) Ambroise Bachot (d.1587), considered the continuous layout of the elliptic with string, and the invention of a tool for the delineation of ellipses (Bachot [20]), in a work that was reprinted and completed and came to be known as Le Gouvernail (Bachot [21]). These methods need a string with a minimum length that is equal to the major axis for the layout of the ellipse.

One of the most influential figures in the theoretical training of Spanish military engineers, Vicente Tosca (1651-1723) (Camara [22]), constructed the figure of the oval based on two axes in De la Geometría Práctica (1707). The apparent difficulty of tracing the oval posed by the suppression of measures to find the centres was alleviated by the method of Tosca (1707). The tracing initially placed the centre of the minor arc on the major axis. This first measurement could be perfectly metrological, while the second centre of the oval, located on the minor axis, can be constructed by a simple squaring operation.

Fray Vicente Tosca (1651-1723) dedicated Volume III of the Compendio mathematico (1710) to Conic Sections, and in Book I he determines various designs De la elypse (Tosca [23]). Previously, in Volume I (1707) he had considered the oval, Treatise III, Book II, De la Geometría Práctica (Prop. XIVXVII), in which (Prop. XV) Describir un óvalo, dados el mayor y menor diámetro, he examined infinite solutions for ovals by establishing the main axes (Tosca [24]). The solution was disseminated in Volume V of the Compendio (1712) which was devoted to civil and military architecture, applied to the different ways of laying out the diminished arch, in Book II Prop. III (Tosca [25]). The method makes the elevations of the oval commensurable, and able to be laid out in such a way that they pass through the axes of the ellipse. 
Thus, the staking out of the Fort of San Jorge is assessed considering different ovals based on the construction of Tosca. These constructions are compared with the elliptical layout developed in the survey of 1984.

\section{Results and discussion}

Based on the construction of Tosca, several ovals are defined through the axes of $23.49 \mathrm{~m}$ and $17.38 \mathrm{~m}$, approximating the area of an ellipse of $320.70 \mathrm{~m}^{2}$. After several iterations, it is found an oval with an equivalent area of $320.70 \mathrm{~m}^{2}$. It has the center of the minor radius located at $7.12 \mathrm{~m}$ from the flank of the Fort, and the major radius at $14.71 \mathrm{~m}$ (Fig. 4).
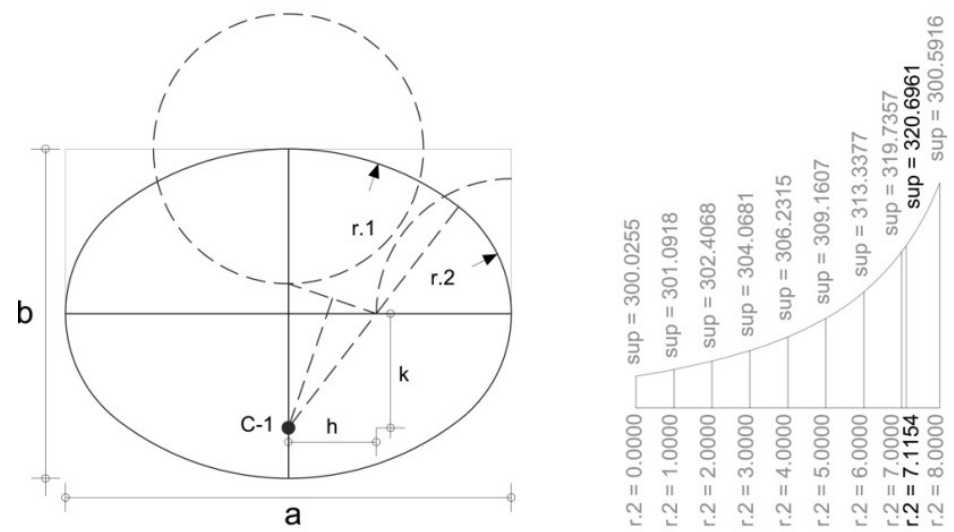

\begin{tabular}{|c|c|c|c|c|c|c|c|c|c|c|c|}
\hline & & 1 & 2 & 3 & 4 & 5 & 6 & 7 & 8 & 9 & 10 \\
\hline & a & 23,49 & 23,49 & 23,49 & 23,49 & 23,49 & 23,49 & 23,49 & 23,49 & 23,49 & 23,49 \\
\hline & b & 17,38 & 17,38 & 17,38 & 17,38 & 17,38 & 17,38 & 17,38 & 17,38 & 17,38 & 17,38 \\
\hline & $x .2$ & 0,00 & 1,00 & 2,00 & 3,00 & 4,00 & 5,00 & 6,00 & 7,00 & 7,12 & 8,00 \\
\hline & $\mathrm{h}$ & 11,75 & 10,75 & 9,75 & 8,75 & 7,75 & 6,75 & 5,75 & 4,75 & 4,63 & 3,75 \\
\hline & k & 3,59 & 3,66 & 3,75 & 3,88 & 4,05 & 4,32 & 4,79 & 5,82 & 6,02 & 9,82 \\
\hline & $\mathrm{r} .1$ & 12,28 & 12,35 & 12,44 & 12,57 & 12,74 & 13,01 & 13,48 & 14,51 & 14,71 & 18,51 \\
\hline & k & 3,59 & 3,66 & 3,75 & 3,88 & 4,05 & 4,32 & 4,79 & 5,82 & 6,02 & 9,82 \\
\hline & $\alpha$ & 17,01 & 18,83 & 21,07 & 23,91 & 27,61 & 32,65 & 39,83 & 50,80 & 52,44 & 69,12 \\
\hline OVAL & AREA & 300,03 & 301,09 & 302,41 & 304,07 & 306,23 & 309,16 & 313,34 & 319,74 & 320,70 & 330,59 \\
\hline ELLIPSE & AREA & 320,70 & 320,70 & 320,70 & 320,70 & 320,70 & 320,70 & 320,70 & 320,70 & 320,70 & 320,70 \\
\hline
\end{tabular}

Figure 4: Comparative surface study of oval and ellipse at Fort of San Jorge (c. 1744).

An extraordinary approximation of both figures is obtained with the construction of the Tosca oval (1707) for San Jorge (c. 1744), and by placing a center of the radius on the alignment of the courtyard wall. In fact, if the two perimeters are compared, in the flanks area, the oval tends to the extrados surface of the ellipse, with a difference of $6.02 \mathrm{~cm}$. Meanwhile, in the central area of the perimeter, the oval tends towards the intrados of the ellipse, with a difference of $4.09 \mathrm{~cm}$. The order of measurement is close to the margin of error of $1 \%$ established in the survey of the Fort (1984). At that time it was determined that the 
perimeter was laid out by an ellipse. After the new studies, the Tosca oval equivalent, which has a minor radius located on the wall of the central courtyard, allows us to hypothesize this second solution, with the perimeter laid out using an oval (Fig. 5).

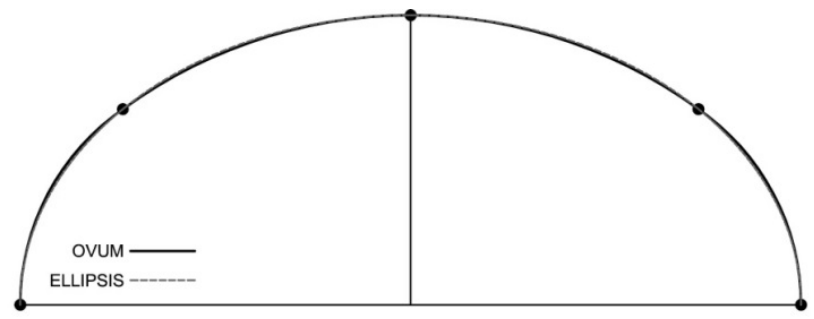

OVUM

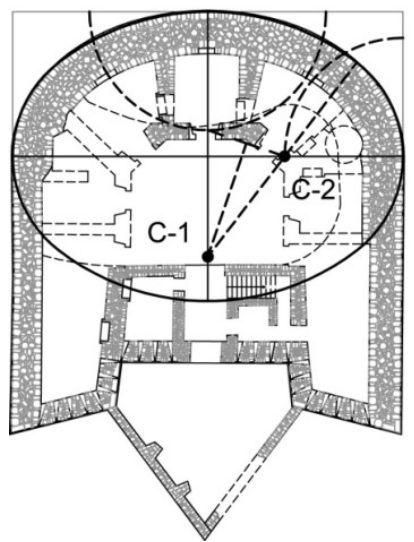

ELLIPSIS

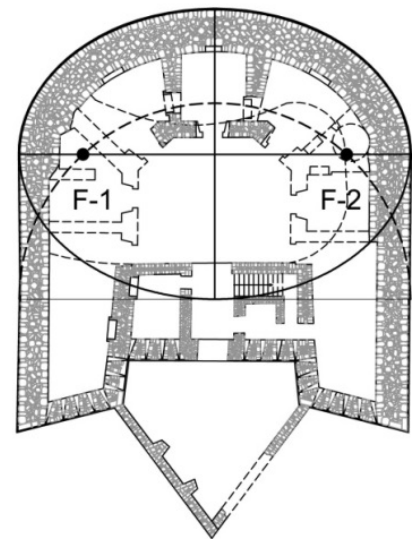

Figure 5: Geometric study of oval and ellipse at the Fort of San Jorge (c.1744).

\section{Conclusions}

The origin of U shaped form in Spain has their origin in the book of Dürer, Etliche underricht zu befestigung der Stett, Schlosz, und flecken (1527). The geometric study of the plans of the U-shaped battery of San Jorge (c. 1744) concludes that they are laid out using ovals by Serlio (1545) and their derivatives. The smallscale delineation of the platforms uses concentric ovals with two centers, as shown by the imprints left by the engineers on the paper, as they are compass points.

Otherwise, the tracing of the " $U$ " shape of the Fort of San Jorge on the ground should have been very different. If the preestablished measures - those on the main axes - are taken as the starting point, the geometric forms for laying out ellipses of Cataneo (1567), and for ovals by Tosca (1707) tend to be very similar. Both represent a similar degree of difficulty in the layout on the ground. Two geometric operations must be performed in order to lay out the wall of the "U" using an 
ellipse, and thereby determine the foci of the concentric ellipses. If this is done using a Tosca oval, the center of the minor radius is set on the major axis, meaning that two geometric operations are also required in order to lay out the other center. The difficulty in laying out the ellipse and the oval for staking on the ground is very similar.

Although the equations which define both figures are mathematically very different, the formal parameterization of the tracing of the U-shaped battery of San Jorge (c. 1744), could be both an oval and an ellipse. The margin of error in any tracing for both figures can be perfectly absorbed in both hypotheses.

\section{References}

[1] González, J.L., Alberto Durero. Tratados de arquitectura y urbanismo militar, Akal: Madrid, 2004.

[2] Dürer, A., Etliche underricht zu befestigung der Stett, Schlosz, und flecken, Hieronymus Andreae: Nürenberg, 1527.

[3] Tello, F.J.L., Arquitectura y Matemáticas según los tratados españoles del siglo XVIII. Implicaciones sociológicas, Anales del Seminario de Metafisica. Núm. Extra. Homenaje a S. Rábade. Ed. Complutense, pp. $767-$ $780,1992$.

[4] De Villegas, E.D. (1651). Academia de fortificación de plazas y nuevo modo de fortificar una plaza real. Madrid: Alonso de Paredes.

[5] Davila, A., Plazas fortificadas en el Ducado que era de Lorena, con un tratado de geometría practica para traçar figuras regulares, Madrid?: s.n., 1672 ?

[6] Chafrión J., Escuela de Palas o Cursos Mathemáticas, En la Emprente Real por Marcos Antonio Pandulpho Malatesta: Milán, 1693.

[7] Migliari, R., Ellissi e ovali. Epilogo di un conflitto. Palladio, 1995 Anno VIII (16): pp. 93-102, 1995

[8] Lucuze, P., Principios de fortificación, que contienen las definiciones de los terminos principales de las obras, Thomas Piferrer: Barcelona, 1772.

[9] Generalitat Catalunya, Catàleg de Monuments $i$ Conjunts HistòricoArtístics de Catalunya. Departament de Cultura: Barcelona, 1990.

[10] Besson J., Instrumentorum et machinarum Quas Jacobus Bessonus Delphinas mathematicus et un machinis practer otras cosas excogitavit: s. 1. s.n. s.d., 1569.

[11] Barrozzi, Admirandum illud geometricum problema tredecim modis demonstratum, quo docet duas líneas, Venitiis Apud Gratiosum Perchacinum, 1586.

[12] Serlio, S., Il Primo libro d'architettura di Sebastiano Serlio, bolognese; Il Secondo libro di perspettia di Sebastiano Serlio bolognese Cornelio di Nicolini da Sabbio: Venecia, 1551.

[13] Serlio, S., Il Primo libro d'architettura di Sebastiano Serlio, bolognese. Le premier libre d'Architecture de Sebastiano Serlio, Bolognoi, mis en lange Francoyse par Iehan Martin., Jean Barbé: París, 1545. 
[14] Rosin, P.L., On Serlio's Constructions of Ovals, The Mathematical Intelligencer, n. 1, 58-69, 2001.

[15] Rojas, C., Teoría y Práctica de fortificación, conforme las medidas y defensas de los tiempos, repartida en tres partes, Luis Sanchez: Madrid, 1598.

[16] Trataglia, N., La Quinta parte del General Trattado de numeri et misure di Nicolo Tartaglia, Curtio Troiano: Venetia, 1560.

[17] Tartaglia, N., Quesiti, et inventioni diverse de Nicolo Tartalea Brisciano. Venturino Rusinelli: Venetia, 1554.

[18] Rojas, C., Teoría y Práctica de fortificación, conforme las medidas y defensas de los tiempos, repartida en tres partes, Luis Sanchez: Madrid, 1598.

[19] Cataneo, P., L'architettura di Pietro Cataneo senese: oltre alla quale todos essere stati dall'istesso autore riuisti, Aldus: Venecia, 1567.

[20] Bachot, A., Le Timon du Capitaine Ab. Bachot, Lequel conduira le lecteur Parmi les guerrières, Au faubourg Saint-Germain-des-Prés: París, 1587.

[21] Bachot, A., Le Gouvernail d'Ambroise Bachot, capitaine ingenieur du Roy: Melun: Imprime l'auteur soubz; et aussi s'en trouuera Son en Logis à Paris, 1598.

[22] Camara, A., La arquitectura militar del padre Tosca y la formación teórica de los ingenieros entre Austrías y Borbones, Ingenieros militares de la Monarquía Hispánica en los siglos XVII y XVIII, Ministerio de Defensa: Madrid, 2005.

[23] Tosca V., Compendio mathematico: Que comprehende Geometria elementar, arithmetica inferior, geometria practica. Tomo I, Antonio Bordazar: Valencia, 1707.

[24] Tosca V., Compendio mathematico: Que comprehende Trigonometria, Secciones Conicas. Maquinaria Tomo III, Antonio Bordazar: Valencia, 1710.

[25] Tosca V., Compendio mathematico: Que comprehende Arquitectura civil, montea, y canteria, arquitectura militar, pirotechnia, y artilleria. Tomo $V$, Antonio Bordazar: Valencia, 1712. 